\title{
Management Commitment, Accounting Information System Usage and Individual Performance on Small and Medium Enterprises (SMEs) in Riau Province, Indonesia
}

\author{
Ruhul Fitrios $^{1 *}$ Ulfa Afifah $^{2}$ Mayla Khoiriyah ${ }^{3}$ Restu Agusti ${ }^{4}$ \\ 1. Faculty of Economics and Business, Accounting Department, Universitas Riau, Pekanbaru, Indonesia \\ 2. Faculty of Economics and Business, Accounting Department, Universitas Riau, Pekanbaru, Indonesia \\ 3. Faculty of Economics and Business, Accounting Department, Universitas Riau, Pekanbaru, Indonesia \\ 4. Faculty of Economics and Business, Accounting Department, Universitas Riau, Pekanbaru, Indonesia \\ * E-mail of the corresponding author: ruhul.fitrios@lecturer.unri.ac.id
}

\begin{abstract}
This study aims to examine the effect of management commitment on the use of accounting information systems, and their impact on individual performance on Small and medium-sized (SMEs) in Riau Province, considering that there are many small and medium enterprises (SMEs) that have not used information systems properly. To prove the phenomena and hypotheses, this study was conducted on 258 medium-sized SMEs in Riau Province. The research method used is descriptive and verification research methods, and statistical analysis using the PLS SEM analysis tool. The results of the study conclude that management commitment has an effect on the use of accounting information systems. The results also conclude that the use of accounting information systems has an impact on individual performance. The results of this study have the implication that to solve the problem of have not using the SMEs accounting information system properly in Riau Province, it can be minimized through strengthening management commitment, so as to improve individual performance.
\end{abstract}

Keywords: Management Commitment, Use of Accounting Information Systems, Individual Performance, Small and Medium Enterprises

DOI: $10.7176 / \mathrm{IKM} / 11-4-15$

Publication date:December $31^{\text {st }} 2021$

\section{Introduction}

The success of an organization, including small business organizations, cannot be separated from the use of information systems. The information system is used adequately to provide the information needed for those who need it for decision-making purposes. Information systems are the main supporting tool for organizational performance. Without an information system, the organization will disband. One of the success factors of a business activity is their ability to strengthen the use of information systems (Hunter, 2015).

DeLone \& McLean (2016) revealed that the use of information systems is a key element for the success of an information system, in addition to the quality of the system being implemented, the quality of the information produced, and the results obtained. The use of the system is the level and manner in which users, both staff and customers, take advantage of the capabilities of an organization's information systems (Petter, DeLone, \& McLean, 2008). The more frequently it is used, the higher the frequency of use, the actual use of the system has an impact on individual and organizational performance (Petter, DeLone, \& McLean, 2008; Hou, 2012). Several studies have proven the large role of using accounting information systems to enhance organizational performance (Trabulsi, 2018). Trabulsi (2018) conducted a study on SMEs in Saudi Arabia, the results prove that the use of AIS has a significant impact on organizational performance in general and on all dimensions, such as: reduction of organizational costs, quality improvement and effective decision making. While Hou (2012) there is a strong influence of the use of information systems on individual performance.

Various facts illustrating the poor utilization/use of accounting information systems in SMEs in Indonesia. including that most of the SME actors who are the driving force of the economy in Indonesia are still blind to accounting, so they cannot know the business conditions of the SMEs they manage, they do not manage assets and are unable to manage business cash flows, so many of these SMEs close their business. Only a small part of SMEs are able to adopt bookkeeping or accounting software, due to the owner's lack of understanding about the benefits of accounting. Based on an interview with Hamsani (2020) as the Head of the SME Division at the Riau 
Province Cooperative and UKM Service, it was found that the use of accounting information systems for SMEs in Riau Province was in a low category. It is further said that although the government has provided accounting information system applications for small and medium enterprises, more than $60 \%$ of small and medium enterprises apply for People's Business Credit.

The owner/management commitment factor refers to the level of commitment of the owners (management) of SMEs in decisions related to the use of accounting information systems in their entities. According to Teo \& Dhaliwal (2006) owners/managers have a key role in encouraging and creating the right atmosphere to facilitate employee acceptance of the use of new accounting information system applications. Inline with that, Mohamad (2012) says that SMEs owners/managers have a better understanding of the company's needs so that they are able to identify the need for appropriate accounting information system applications to support the needs. The results of the research of Teo \& Dhaliwal (2006) and Scupola (2009) prove that the commitment of the owner/manager to adopt an information system is proven to have a significant effect on the success of using an accounting information system.

Based on the description above, this study aims to examine the effect of management commitment on the use of accounting information systems and their effect on individual performance. This study also aims to examine the direct effect of management commitment on individual performance

\section{Literature Review}

\subsection{Management Commitment and Use of Accounting Information System}

Management commitment is the most important factor to build or develop the organization, determine decisions to improve processes, show the desire and strength of heart to make changes, encourage senior managers to support changes that must occur (Sheard, 2001). Management commitment as management's involvement in maintaining the behavior of people who encourage the person to achieve goals (Cooper, 2006). Rationally in relation to AIS, when management considers information systems as important, they will ensure adequate resource allocation for the smooth use and implementation of information systems. Management can reduce organizational resistance in using information systems by providing strategic vision, initiative, commitment, and long-term support to create a suitable environment for using information systems.

An accounting information system is a set of subsystems or related components to process financial data and become useful financial information for the purposes of decision-making (Fitrios, et al., 2018). The use of this system is characterized by intention to use, frequency of use, self-reported use, and actual use (Petter, DeLone \& McLean, 2008). In another part, O'brien \& Marakas (2011:17) state that the success of an information system should not be measured only by its efficiency in terms of minimizing costs, time, and the use of information resources. Success should also be measured by the effectiveness of information technology in supporting the organization's business strategy, enabling its business processes, improving organizational structure and culture, and increasing customer value and company business.

Top management commitment is an important factor to help operational managers successfully implement accounting information systems, otherwise the information system will fail (Schwalbe, 2014). Management plays a key role to encourage and create the right atmosphere to bridge the recruitment of employees with the use of new information system applications (Teo \& Dhaliwal, 2006). Therefore, the use of an accounting information system requires a high commitment and management from various levels of management to ensure that all planned procedures are carried out properly, so that the information system built can be utilized as well as possible (Laudon \& Laudon, 2016). Furthermore, problems using information system applications can be identified correctly to support company needs, when MSME management has a better understanding of the company's needs (Mohamad, 2012).

The results of research by Fauziah et al., (2020) prove that the commitment of owners of small businesses has an effect on the use of accounting information for small businesses in Pekanbaru City. Likewise, the results of research by Fadjar et al. (2021) concluded that management commitment has a significant effect on the use of accounting information systems at Bank Rakyat Indonesia (BRI) in Bandung. The results of Amiruddin \& Raharja's research (2019) show that management commitment is needed not only at the beginning of the project, but also during the implementation and operation of the company's computerized information system to achieve business goals.

Hipothesis 1 . the management commitment affects the use of accounting information systems. 


\subsection{Use of Accounting Information Systems and Individual Performance}

Individual performance is a set of individual behaviors or actions that individuals have that are relevant to organizational goals (Campbell, 1990). In addition, individual performance is the result of affective commitment, work resources and creativity owned by the individual concerned (Semedo et al., 2016). Employees who perceive work more as a calling than a job solely to earn money show good performance (Rego et al., 2007). Individual performance possessed by a person is described by quality in decision making, work performance obtained, individual productivity, effectiveness in carrying out work, speed in problem identification, speed in decision making, and breadth of analysis in decision making (Hou. 2012).

The impact of the use of accounting information systems on individual performance can be seen from the actual performance of individuals who use information systems (Huo, 2012). The use of information systems can improve individual performance, such as: increasing individual productivity, increasing job performance, increasing decision-making effectiveness, and strengthening problem identification skills (DeLone \& McLean, 2016). Luo \& Ling, (2013) prove that there is an effect of using the system on individual employee performance. The use of exploitative and exploratory information systems has different effects on individual performance, but both uses are positively related to individual performance. The results of other studies in government units prove that the use of accounting information systems affects the performance of individual workers (Sahusilawane, 2015). In addition, Moussaa \& El Arbi (2020) also prove that human resource information systems are able to increase employee innovation in Tunisia.

Hypothesis 2. Based on the description above, the use of accounting information systems affects on individual performance

\subsection{Management Commitment and Individual Performance}

The Effect of Management Commitment on individual Performance Management commitment refers to the efforts made by management to create a work environment that is suitable for the achievement of organizational goals, ensuring the availability of sufficient financial and non-financial resources. Strong management commitment motivates and stimulates the people in organization to improve its performance (Gronfeldt \& Strothe, 2006:94). Rod \& Ashill (2010) revealed that management commitment given to employees in the form of giving rewards, customer service training, empowerment, and providing customer service orientation will encourage employee affective outcomes and result in service recovery performance. The same thing is also concluded by Babakus, et al., (2003) that commitment management can improve individual worker performance which is proxied on service recovery performance, mediated by employee affective commitment. The results of research by Loan (2020) prove that management commitment a positive impact on job performance of employee.

Hypothesis 3. Based on the description above, the SMEs management commitment has an effect on individual performance.

The theory that is built within the conceptual framework is described in the research model, in Figure below:

\section{in the research model, in Figure below:}

\section{Research Method}

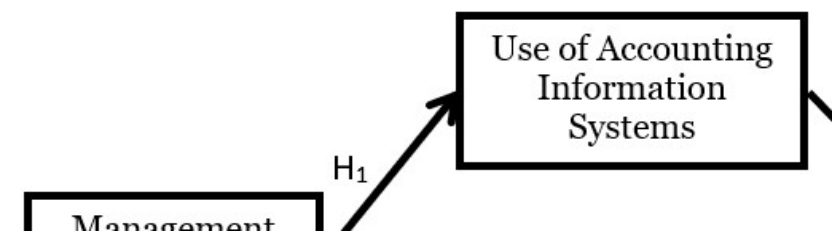

The population of this research is all SMEs in the Riau Province and recorded at the Small and Medium Business Cooperative Trade Office of Riau Province, with a target population of SMEs in the medium-sized business group, on the grounds that medium-sized businesses have used accounting software applications in preparing financial reports. Furthermore, the unit of analysis in the sampled SMEs is the financial unit, because in this unit the process of preparing financial reports is carried out. While the unit of observation is the leadership and people in the finance department who are involved in processing the preparation of financial statements. The 
population of medium-sized business groups registered with SMEs in Riau Province is 3,702 business units. Based on the calculation of sample formula, the number of samples was determined to be 360 sample units. The sampling technique used to select the selected sample is a stratified random sampling technique. Data is collected using a questionnaire, which is distributed by means of online provision and delivered to the location. Of this number, $264 \mathrm{SME}$ business units returned the questionnaire, and 258 samples could be processed.

Management commitment is defined as the engagement and effort to maintain behavior to help others achieve their goals (Cooper, 2006). Management commitment is measured using indicators developed by Lutfi et al., (2017), namely: 1) involvement in planning; 2) fulfillment of hardware and software needs; 3) involvement in implementation; and 4) activity evaluation. Measurement of these indicators is carried out by providing statements about what happens, is done, seen and felt by accounting employees regarding management commitment, using a Likert scale with varying conditions from 1 (never) to 5 (always).

System use is the level and way in which employees and customers take advantage of the capabilities of an information system (Delone \& McLean, 2016). The use of the system is measured using indicators developed by Delone \& McLean, (2016), namely: 1) the number of uses; 2) frequency of use; 3) nature of use; 4) suitability of use; 5) usage rate; and 6) intended use. Measurement of these indicators is carried out by providing statements about what happened, was done, seen and felt about the use of AIS, using a Likert scale with varying conditions from 1 (never) to 5 (always).

Individual performance is the result of affective commitment, work resources and creativity possessed by the individual concerned (Semedo et al., 2016). Organizational performance is measured using indicators developed by Delone \& Mclean, (2016) consisting of: work effectiveness, decision time, productivity and task performance. Measurement of indicators is carried out by giving statements about what is enjoyed and felt about performance, using a Likert scale with varying conditions from 1 (never) to 5 (always).

Percentage Total 258 respondents who returned from 360 samples of at least $71.67 \%$ were considered sufficient to meet a survey research to proceed to the data processing stage. Sekaran (2013) states that a minimum response rate of $30 \%$ can be considered for acceptance in the study.

The data analysis method used in this research is the quantitative analysis method, it is descriptive statistical analysis and hypothesis testing using SPSS and Structural Equation Model - Partial Least Square (SEM-PLS). The descriptive statistical analysis describes data analysis by describing the characteristics of existing data and is not intended to draw general conclusions (Sugiyono, 2017). In this study, descriptive statistical analysis was used to obtain an overview of the characteristics of research respondents regarding management commitment, individual performance impact, and the use of accounting information systems (AIS usage). The verification test in this study uses variance-based structural equation modeling analysis using Smart PLS software. SEM is used to answer the problem formulation and prove the truth of the research hypothesis because SEM is an analytical technique to test and estimate causal relationships.

Table 1. Description of Respondent

\begin{tabular}{|c|c|c|}
\hline Description & Frequency & Percent \\
\hline \multicolumn{3}{|l|}{ Gender: } \\
\hline Male & 120 & 47 \\
\hline Female & 138 & 53 \\
\hline Total & 258 & 100 \\
\hline \multicolumn{3}{|l|}{ Position } \\
\hline Administrative/Finance Staff & 124 & 48 \\
\hline Head of Division & 36 & 14 \\
\hline Manager & 23 & 9 \\
\hline Owner & 75 & 19 \\
\hline Total & 258 & 100 \\
\hline
\end{tabular}

The evaluation of the measurement model is intended to determine the feasibility of the inner model that has been built based on the theory, through evaluating the validity and reliability of the construct indicators used. Evaluation of the Structural Model or outer model is carried out to see the significance of the relationship between constructs, through the path coefficient, the R2 value which shows the variability of endogenous variables that can be explained by exogenous variables, and hypothesis testing to show the presence or absence of the influence of exogenous variables on endogenous variables obtained from test the path coefficients (path 
coefficients/standard beta).

Table 2: Outer Loading

\begin{tabular}{|l|r|r|r|r|}
\hline & $\begin{array}{c}\text { Original } \\
\text { Sample (O) }\end{array}$ & $\begin{array}{c}\text { Standard Deviation } \\
(\text { STDEV })\end{array}$ & $\begin{array}{c}\text { T Statistics } \\
(\mid \mathrm{O} / \mathrm{STDEV})\end{array}$ & P Values \\
\hline MC1 <- Management Commitment & 0.883 & 0.015 & 60.106 & 0.000 \\
\hline MC2 <- Management Commitment & 0.890 & 0.013 & 68.241 & 0.000 \\
\hline MC3 <- Management Commitment & 0.919 & 0.011 & 81.752 & 0.000 \\
\hline MC4 <- Management Commitment & 0.881 & 0.022 & 40.785 & 0.000 \\
\hline MC5 <- Management Commitment & 0.891 & 0.014 & 65.741 & 0.000 \\
\hline OP1 <- Individual Performance & 0.923 & 0.013 & 71.915 & 0.000 \\
\hline OP2 <- Individual Performance & 0.943 & 0.008 & 111.705 & 0.000 \\
\hline OP3 <- Individual Performance & 0.908 & 0.012 & 75.558 & 0.000 \\
\hline OP4 <- Individual Performance & 0.868 & 0.024 & 36.340 & 0.000 \\
\hline SU1 <- AIS Usage & 0.905 & 0.013 & 69.795 & 0.000 \\
\hline SU2 <- AIS Usage & 0.865 & 0.021 & 41.072 & 0.000 \\
\hline SU3 <- AIS Usage & 0.880 & 0.010 & 87.282 & 0.000 \\
\hline SU4 <- AIS Usage & 0.876 & 0.017 & 52.818 & 0.000 \\
\hline SU5 <- AIS Usage & 0.902 & 0.015 & 61.561 & 0.000 \\
\hline SU6 <- AIS Usage & 0.760 & 0.039 & 19.468 & 0.000 \\
\hline
\end{tabular}

\section{Results and Discussions}

\subsection{Validity and Reliability Test}

Validity test results are obtained through convergent validity and discriminant validity. The outer loading factor of each indicator, as presented in Table 3, shows a value of more than 0.6 and a t-statistic value of more than 1.96. In addition, the AVE test results show that the AVE value of each construct is above 0.5 (Table 4).

\section{Table 3: Cross Loading}

\begin{tabular}{|l|c|c|c|}
\hline & $\begin{array}{c}\text { Management } \\
\text { Commitment }\end{array}$ & $\begin{array}{c}\text { AIS } \\
\text { Usage }\end{array}$ & $\begin{array}{c}\text { Individual } \\
\text { Performance }\end{array}$ \\
\hline MC1 & 0.883 & 0.670 & 0.693 \\
\hline MC2 & 0.890 & 0.768 & 0.700 \\
\hline MC3 & 0.919 & 0.775 & 0.700 \\
\hline MC4 & 0.881 & 0.664 & 0.673 \\
\hline MC5 & 0.891 & 0.674 & 0.636 \\
\hline SU1 & 0.693 & 0.905 & 0.582 \\
\hline SU2 & 0.653 & 0.865 & 0.501 \\
\hline SU3 & 0.777 & 0.880 & 0.621 \\
\hline SU4 & 0.689 & 0.876 & 0.597 \\
\hline SU5 & 0.710 & 0.902 & 0.673 \\
\hline SU6 & 0.606 & 0.760 & 0.724 \\
\hline OP1 & 0.703 & 0.627 & 0.923 \\
\hline OP2 & 0.712 & 0.647 & 0.943 \\
\hline OP3 & 0.664 & 0.648 & 0.908 \\
\hline OP4 & 0.697 & 0.685 & 0.868 \\
\hline
\end{tabular}

The discriminant validity test also meets the criteria. The results of the cross loading test in table 4 show that the correlation value of the indicators on each construct of management commitment, use of accounting information systems, and individual performance is higher than the correlation value of other constructs. In addition, the value of the square root of the construct is higher than the correlation with other constructs, as presented in table 4. Based on the evaluation above, it can be concluded that the measurement model is valid. 


\section{Table 4: The Square Root of AVE}

\begin{tabular}{|c|c|c|c|c|c|c|}
\hline \multirow[b]{2}{*}{ Variabel } & \multirow{2}{*}{$\begin{array}{c}\text { Average } \\
\text { Variance } \\
\text { Extracted } \\
\text { (AVE) }\end{array}$} & \multicolumn{3}{|c|}{ Root of AVE } & \multicolumn{2}{|c|}{ Reliability } \\
\hline & & $\begin{array}{l}\text { Management } \\
\text { Commitment }\end{array}$ & $\begin{array}{l}\text { System } \\
\text { Use }\end{array}$ & $\begin{array}{c}\text { Individual } \\
\text { Performance }\end{array}$ & $\begin{array}{l}\text { Cronbach's } \\
\text { Alpha }\end{array}$ & $\begin{array}{l}\text { Composite } \\
\text { Reliability }\end{array}$ \\
\hline Man Commitment & 0.797 & 0.893 & & & 0.936 & 0.952 \\
\hline System Use & 0.750 & 0.798 & 0.866 & & 0.933 & 0.947 \\
\hline $\begin{array}{l}\text { Individual } \\
\text { Performance }\end{array}$ & 0.830 & 0.763 & 0.716 & 0.911 & 0.931 & 0.951 \\
\hline
\end{tabular}

\subsection{Hypothesis Testing (Structural model evaluation)}

Hypothesis testing was carried out through evaluation of the structural model. Evaluation of structural models is used to prove how empirical data supports the concepts or theories that are constructed and generate hypotheses (Hair, 2014).

Table 5: Path Analysis \& R Square

\begin{tabular}{|l|r|r|r|r|r|r|}
\hline & $\begin{array}{c}\text { Original } \\
\text { Sample } \\
(\mathrm{O})\end{array}$ & $\begin{array}{c}\text { Standard } \\
\text { Deviation } \\
(\text { STDEV })\end{array}$ & $\begin{array}{c}\text { T Statistics } \\
(\mid \mathrm{O} / \text { STDEV } \mid)\end{array}$ & P Values & $\begin{array}{c}\text { R } \\
\text { Square }\end{array}$ & $\begin{array}{c}\text { R Square } \\
\text { Adjusted }\end{array}$ \\
\hline $\begin{array}{l}\text { Management Commitment }-> \\
\text { AIS Usage }\end{array}$ & 0.798 & 0.029 & 27.856 & 0.000 & 0.636 & 0.635 \\
\hline $\begin{array}{l}\text { AIS Usage -> Individual } \\
\text { Performance }\end{array}$ & 0.297 & 0.069 & 4.270 & 0.000 & 0.614 & 0.611 \\
\hline $\begin{array}{l}\text { Management Commitment }-> \\
\text { Individual Performance }\end{array}$ & 0.526 & 0.066 & 7.933 & 0.000 & & \\
\hline
\end{tabular}

\section{$4.3 R$ Square evaluation results}

The results of the R Square evaluation show that the R Square value of the AIS Usage is 0.636. These results indicate that the constructs of management commitment are able to explain the use of AIS by $63.60 \%$, while the remaining $36.40 \%$ is explained by other variables. Furthermore, the variable using SIA is able to explain individual performance by $61.40 \%$, while the remaining $38.60 \%$ is explained by other variables.

\subsection{Hypothesis Test Results}

Hypothesis testing is intended to determine the effect of management commitment to the use of AIS and the use of AIS on individual performance. The results of the hypothesis test of management commitment to the use of AIS show that the $t$ statistic of management commitment shows a value of 27.856 greater than 1.96 with a $\mathrm{P}$ value of 0.000 less than 0.05 . These results prove that commitment has an significant effect on the use of AIS with a magnitude of 0.798 . Furthermore, the results of hypothesis testing the effect of using AIS on individual performance show that the $t$ statistic of the use of AIS shows a value of 4.270 greater than 1.96 with a $P$ value of more than 0.000 less than 0.05 , and a path value of 0.297 . These results indicate that the use of accounting information systems has an effect on individual performance with a large influence of 0.297. The results of hypothesis testing the direct effect of management commitment on individual performance show that the $t$ statistic of the use of AIS shows a value of 7.933 greater than 1.96 with a P value of more than 0.000 less than 0.05 , and a path value of 0.526 . These results indicate that management commitment has an effect on individual performance with a large influence of 0.526 .

\subsection{The effect of management commitment on the use of AIS}

These results prove that management commitment has a positive effect on the use of AIS. It can also be interpreted that every 1 degree increase in management commitment will increase the use of accounting information systems by 0.798 degrees. This research is able to prove the role of management commitment in the use of accounting information systems in SMEs in Riau Province. The factor causing this to happen is because the commitment of the SME management is still weak. Management has not actively planned and operationalized the proper use of AIS, has not been actively involved in providing appropriate AIS hardware and software, is not involved in the implementation of AIS, management is not able to solve problems related to the use of AIS, and has not planned further AIS development. 
Based on the results of research to develop and improve the use of accounting information systems, it is necessary to strengthen management commitment in planning involvement, providing hardware software, problem solving, and being involved in the development of AIS. Then in line with the opinion of Ham, Gon \& Jeong (2005), it is important to increase the effective use of AIS, because it will help them to increase productivity, create competitive advantage, save costs over time and increase revenue.

The results of this study strengthen the opinion of Dezdar \& Ainin (2011) where management must be able to provide a strong commitment to a system project, if you want to be successful in implementing accounting information systems, so that accounting information systems can be used optimally by users of information systems. Thus, based on the results of this study, it can be concluded that management commitment has an effect on the use of AIS of SMEs in Riau Province.

\subsection{The effect of using AIS on individual performance}

The results of the study prove that the use of AIS has a positive effect on individual performance. This study is able to prove the magnitude of the role of the use of accounting information systems on the individual performance of MSMEs in Riau Province. The factor that causes this to happen is because the use of AIS SMEs is still low. The use of AIS that is still low is indicated by the use of AIS that is not carried out every day to input transactions and provide reports to management, the level of use is still low, the use of which is not yet computerized, and the preparation of financial statements is still difficult and slow, so that the provision of accounting information is not timely. The use of AIS has an impact on individual performance that is not optimal, such as work effectiveness, work productivity, work performance, and the quality of individual decision making.

Therefore, it is necessary to strengthen the use of information systems, so as to improve individual performance, such as: increasing individual productivity, increasing job performance, increasing decision-making effectiveness, and strengthening problem identification skills (DeLone \& McLean, 2016). that the use of exploitative and exploratory information systems has different effects on individual performance (Luo \& Ling, 2013). The results of this study further strengthen the results of previous studies which prove the large role of using accounting information systems to improve individual performance (Trabulsi, 2018; Hou, 2012). Thus, based on the results of this study, it can be concluded that the use of AIS has an effect on the individual performance of SMEs in Riau Province.

\subsection{The effect of management commitment on individual performance.}

The results of the study prove that management commitment directly has a positive effect on individual performance. This study is able to prove that management commitment plays a strong enough role in the individual performance of MSME employees in Riau Province. This low individual performance is caused by the low management commitment in managing the company. Individual performance in SME organizations requires management commitment in terms of proper planning and management of AIS, provision of required hardware and software, and development of required AIS. Therefore, it is important to have a strong management commitment to motivate and stimulate the people involved in the organization, so as to strengthen individual performance (Loan, 2020). The results of this study strengthen the research results of Kiani \& Tanabandeh (2016) that management commitment has a strong relationship with individual performance in organizations. Thus, based on the results of this study, it can be concluded that management commitment has an effect on individual performance of SMEs in Riau Province.

\section{Conclusion}

Management commitment affect the use of accounting information systems for SMEs in Riau Province. Furthermore, the use of accounting information systems affects the individual performance of SMEs. The weak use of SME accounting information systems in Riau Province can be seen from the lack of daily use, low frequency of use, not yet computerized AIS, untimely presentation, level of use and level of ease of preparing reports, so that it has an impact on individual performance. To increase the use of accounting information systems, management commitment are needed, so that individual performance can be improved.

The results of this study were able to solve the problem of the low use of accounting information systems for SMEs in Riau Province through strengthening management commitment in maximizing the use of accounting information systems. 


\section{References}

Amiruddin, D., \& Raharja, S.J. (2019) Commitment Management as a Determining Factor in the Successful ERP Implementation at Manufacturing Companies. Advances in Social Science, Education and Humanities Research, volume 410

Babakus, E., Yavas, U., \& Avci, O.M.K.T. (2003). The Effect of Management Commitment to Service Quality on Employees' Affective and Performance Outcomes. Journal of the Academy of Marketing Science. 31(3), 272-286.

Barton, K.A., Tejay, G., Lane, M., Terrell, S. (2016). Information system security commitment: A study of external influences on senior management. Computers \& Security, 59 (2016), 9-25.

Campbell, J. (1990). "Modeling the performance prediction problem in industrial and organizational psychology”, in Dunnette, M. and Hough, L. (Eds), Handbook of Organizational and Industrial Psychology, Consulting Psychologists Press, Palo Alto, 687-732.

Cooper, M.D. (2006). Exploratory analyses of managerial commitment and feedback consequences on behavioral safety maintenance. Journal of Organizational Behavior Management, 26(3), 1-41.

Delone, W.H., \& McLean E.R. (2016). Information system success measurement, Foundation and Trends in Information Systems, 2(1), 1-116.

Dezdar, S., \& Ainin, S. (2011). The influence of organizational factors on successful ERP implementation, Management Decision, 49(6), 911-926.

Fadjar, A., Sukandi, D., Mentari, R., Sihombing, F., \& Hasbiya, R.M. (2021). Management Commitment, Accounting Information Systems and Quality of Accounting Information. Psychology and Education Journal, 58(3), 564-572.

Fauziah, M., Fitrios, R., \& Syofyan, A. (2020). Pengaruh komitmen pemilik dan dukungan pemerintah terhadap penggunaan sistem informasi akuntansi (The Effect of Government Support Fund Owner's Commitment on the Use of Accounting Information Systems), Jurnal Riset Akuntansi Tirtasyasa, 6(1), 82-92.

Fitrios, R., Susanto, A., Soemantri, R., \& Suharman, H. (2018). The Role of Leadership Behavior in Improving The the Quallity of Accounting Information Systems. Journal of Engineering and Applied Sciences, 12 (12), 4493-4501.

Gronfeldt, S., \& Strother, J. (2006). Service leadership: The quest for competitive advantage. Thousands Oaks, CA: Sage Publications.

Hair, Jr, JF., Hult, GTM. Ringle. CM. \& Sarstedt M. (2017). A Primer on Partial Least Squares Structural Equation Modeling (PLS-SEM). $2^{\text {nd }}$, Sage Publications, Inc. Los Angeles 13.

Ham, S., Gon Kim, W., \& Jeong, S. (2005). Effect of information technology on performance in upscale hotels. International Journal of Hospitality Management, 24(2), 281-294.

Hameed, M. A., Counsell, S \& Swift, S. (2012). A meta-analysis of relationships between organizational characteristics and IT innovation adoption in organizations. The Journal of Information \& Management, 49(2012), 218-232.

Hou, C., K. (2012). Examining the effect of user satisfaction on system usage and individual performance with business intelligence systems: An empirical study of Taiwan's electronics industry, International Journal of Information Management, 32 (2012), 560-573.

Hunter, M.G. (2015). Strategic Utilization of Information System in Small Business, IGI Global, Hersey PA, USA.

Kiani, M.P., \& Tanabandeh, M. (2016). Explaining the relationship between management commitment to service quality, job satisfaction, and organizational performance in the staff of Islamic Republic of Iran's Custom. International Journal of Humanities and Cultural Studies, Spesial Issue(2016), 101-115.

Laudon, K. C., \& Laudon, J.P. (2016). Management Information System: Managing the Digital Firm, Fourteenth Edition, London, Pearson Education Limited.

Loan, L.T.M. (2020). The influence of organizational commitment on employees' job performance: The mediating role of job satisfaction. Management Science Letters, 10 (2020), 3307-3312.

Luo, Y. \& Ling, H. (2013). Exploration and Exploitation of Information Systems Usage and Individual 
Performance, Procedia Computer Science, 22(2013), 863-872.

Lutfi, A.A., Idris, K.M., \& Mohamad, R. (2017). AIS usage factors and impact among Jordanian SMEs: The moderating effect of environmental uncertainty, Journal of Advanced Research in Business and Management Studies, 6 (1), 24-38.

Moussaa, N.B., \& El Arbi, R. (2020) The impact of Human Resources Information Systems on individual innovation capability in Tunisian companies: The moderating role of affective commitment. European Research on Management and Business Economics 26 (2020) 18-25.

O’Brien, J.A. \& Marakas, G.M. (2011). Management Information System. Teenth Edition. 2011. Published by McGraw-Hill. Irwin.

Petter, S. DeLone, W. \& McLean, E. 2008. Measuring Information Systems Success: models, dimensions, measures, and interrelationships. European Journal of Information Systems 17, 236-263 \& 2008.

Rod, M., \& Ashill, N.J. (2010). Management commitment to service quality and service recovery performance A study of frontline employees in public and private hospitals. International Journal of Pharmaceutical and Healthcare Marketing, 4(1), 84-103.

Sahusilawane (2015), The Impact of effectiveness to use and trust of local financial and information system (SIKD) to individual performance in southeast moluccas. Procedia - Social and Behavioral Sciences 211 (2015) $960-965$.

Scupola, A. (2009). SMEs' e-commerce adoption: perspectives from Denmark and Australia. Journal of Enterprise Information Management, 22(1/2), 152-166.

Schwalbe, K. (2014). Information Technology Project Management, Seventh Edition. Course Technology, Cengage Learning.

Sekaran. U \& Bougie, R. (2013). Research Methods for Business, A Skill Building Approach. Sixth Edition. John Wiley \& Sons, Inc.

Semedo, A.S.D., Coelho, A.F.M., \& Ribeiro, N.M.P. (2016). Effects of authentic leadership, affective commitment and job resourcefulness on employees' creativity and individual performance. Leadership \& Organization Development Journal, 37(8), 1038-1055.

Sheard, S. (2001). What Is Senior Management Commitment?, Software Productivity Consortium.

Sugiyono. (2017). Metode Penelitian Kuantitatif dan R \& D. Cetakan Ketigabelas. Penerbit Alfabeta, Bandung.

Teo, T. S., Ranganathan, C., \& Dhaliwal, J. (2006). Key dimensions of inhibitors for the deployment of webbased business-to-business electronic commerce. IEEE Transactions on Engineering Management, 53(3), 395 411.

Trabulsi, (2018). The Impact of Accounting Information Systems on Organizational Performance: The Context of Saudi's SMEs, International Review of Management and Marketing, 8(2), 69-73.

Wang, H. J., \& Lo, J. (2016). Adoption of open government data among government agencies.Government Information Quarterly, 33(1), 80-88. 